\title{
Doping Control Analysis of 16 Non-Steroidal Anti-Inflammatory Drugs in Equine Plasma Using Liquid Chromatography-Tandem Mass Spectrometry
}

\author{
Youwen You ${ }^{*}$, Cornelius E. Uboh ${ }^{2}$, Fuyu Guan', Lawrence R. Soma ${ }^{1}$ \\ ${ }^{1}$ Department of Clinical Studies, School of Veterinary Medicine, University of Pennsylvania, \\ Kennett Square, PA, USA \\ ${ }^{2}$ PA Equine Toxicology \& Research Center, West Chester University, \\ West Chester, PA, USA \\ Email: *ywyou@vet.upenn.edu
}

Received 28 September 2014; revised 14 November 2014; accepted 29 November 2014

Academic Editor: Schalk de Kock, The Laboratory of The National Horseracing Authority of Southern Africa Turffontein Racecourse, South Africa

Copyright (C) 2014 by authors and Scientific Research Publishing Inc.

This work is licensed under the Creative Commons Attribution International License (CC BY).

http://creativecommons.org/licenses/by/4.0/

c) (i) Open Access

\section{Abstract}

Non-steroidal anti-inflammatory drugs (NSAIDs) are classified as Class 4 agents by the Association of Racing Commissioners International and are banned in racehorses during competition in Pennsylvania (PA). To control the abuse of these agents in racehorses competing in PA, a forensic method for screening and confirmation of the presence of these agents is needed. Equine plasma $(0.5 \mathrm{~mL})$ was acidified with $75 \mu \mathrm{L} 1 \mathrm{M} \mathrm{H}_{3} \mathrm{PO}_{4}$ to increase recovery of the analytes by liquid-liquid extraction using methyl tert-butyl ether (MTBE). Extracted analytes were separated by reversedphase liquid chromatography using a $C_{8}$ column under gradient condition. All 16 analytes were detected, quantified and confirmed using a triple quadrupole tandem mass spectrometry with selected reaction monitoring (SRM) in both negative and positive electrospray ionization modes. The limit of detection, quantification and confirmation of the analytes were $1.0-5.0 \mathrm{ng} / \mathrm{mL}, 1.0$ $5.0 \mathrm{ng} / \mathrm{mL}$ and $1.0-20 \mathrm{ng} / \mathrm{mL}$, respectively. The linear dynamic range of quantification was 5.0 $200 \mathrm{ng} / \mathrm{mL}$. The method is routinely used in anti-doping analysis to control the abuse of NSAIDs in racehorses competing in PA.

\section{Keywords}

Equine Plasma, Doping Control, Non-Steroidal Anti-Inflammatory Drugs, Liquid

\footnotetext{
${ }^{*}$ Corresponding author.
}

How to cite this paper: You, Y.W., Uboh, C.E., Guan, F.Y. and Soma, L.R. (2014) Doping Control Analysis of 16 Non-Steroidal Anti-Inflammatory Drugs in Equine Plasma Using Liquid Chromatography-Tandem Mass Spectrometry. American Journal of Analytical Chemistry, 5, 1184-1199. http://dx.doi.org/10.4236/ajac.2014.517126 


\section{Chromatography-Mass Spectrometry}

\section{Introduction}

Non-steroidal anti-inflammatory drugs (NSAIDs) are structurally classified as carboxylic or enolic acids. Nearly all NSAIDs share an acidic character $\left(\mathrm{pK}_{\mathrm{a}} 3\right.$ - 4) and some are extensively bound to plasma proteins [1]-[5]. Although most NSAIDs are organic acids, they are chemically unrelated and structurally different. Based on the chemical structures, they can be classified into several sub-classes: 1) salicylates; 2) propionic acid derivatives; 3) aryl and heteroarylacetic acid derivatives; 4) anthranilates; 5) oxicams; 6) phenylpyrazolones and 7) anilides.

NSAIDs are used for the treatment of myositis, traumatic osteoarthritis, and other inflammatory conditions in horses [6]-[9]. The major mechanism that contributes to the pharmacological actions of NSAIDs is related to inhibition of cyclooxygenase (COX-1, COX-2), key enzymes involved in biosynthesis of prostaglandins and thromboxanes at the site of inflammation [9]. Since the early 1970s, NSAIDs have been routinely used in veterinary medical practice. In the racehorse industry, NSAIDs are widely used to mask debilitating signs of inflammation and pain in racehorses, and pain-masking property of NSAIDs may result in severe injuries that could end the racing life of the horse, rider or driver [8]. For these reasons, most NSAIDs are banned in PA during competition. However, for therapeutic purposes, two NSAIDs, phenylbutazone and flunixin, are allowed in racehorses at a regulatory threshold concentration in plasma during competition. For all other NSAIDs, detection of any concentration in plasma during competition is a violation. Although phenylbutazone and flunixin are allowed during competition for therapeutic purposes, the presence of both drugs in plasma at the same time during competition, known as "stacking”, is also banned in PA. In order for the PA Racing Commissions to regulate the use of NSAIDs in racehorses, maintain the integrity of racing and protect the health, safety and welfare of the horse, a sensitive method of detecting multiple NSAIDs at low plasma concentrations was needed.

A number of methods have been developed for detecting a single or a group of NSAIDs in human and animal biological matrices using high performance liquid chromatography (HPLC) [10]-[15], capillary electrophoresis [16], gas chromatography-mass spectrometry [17]-[19] and liquid chromatography-mass spectrometry [20]-[24]. These methods focused mainly on quantification of one or a few NSAIDs in biological matrices but were not for anti-doping control analysis, for which the method should be able to detect as many drug suspects as possible during screening and provide unequivocal evidence to demonstrate confirmation of the analyte. Today, this major forensic requirement in confirmation analysis is achieved by LC-MS/MS technology using retention time and mass spectrum as criteria.

Due to the large number of test samples that are received daily by laboratories involved in doping control analysis, methods with high through-put and confirmation capability are the most attractive. Currently, such a method for NSAIDs anti-doping control analysis is not available. For this purpose, a method capable of simultaneous analysis of the most commonly used NSAIDs in equine medical practice was developed and validated. The 16 NSAIDs included in the present study were diclofenac, fenoprofen, flufenamic acid, flunixin, indomethacin, indoprofen, ketoprofen, ketorolac, meclofenamic acid, mefenamic acid, 6-methoxy-2-naphthylacetic acid (6-MNA), naproxen, oxyphenbutazone, phenylbutazone, tolmetin and zomepirac (Figure 1). The method focuses on screening, quantification and confirmation of all 16 NSAIDs in equine plasma.

\section{Experimental}

\subsection{Chemicals and Reagents}

Reference standards of diclofenac, fenoprofen, flufenamic acid, indomethacin, indoprofen, meclofenamic acid, mefenamic acid, 6-MNA, naproxen, tolmetin and zomepirac were purchased from Sigma Aldrich (St. Lois, MO, USA). Flunixin, ketoprofen, ketorolac, oxyphenbutazone and phenylbutazone were obtained from US Pharmacopeia (Rockville, MD, USA), whereas 6-MNA was purchased from Cayman Chem (Ann Arbor, Michigan, USA). $d_{9}$-phenylbutazone (internal standard $1, \mathrm{IS}_{1}$ ) and clonixin (internal standard 2, $\mathrm{IS}_{2}$ ) were purchased from Neogen Corporation (Lexington, KY, USA), and Schering Corporation (Kenilworth, NJ, USA), respectively. Methyl tert-butyl ether (MTBE) and ammonium hydroxide were purchased from EMD Chemical, Inc. (Gibb- 
<smiles>O=C(O)Cc1ccccc1Nc1c(Cl)cccc1Cl</smiles>

Diclofenac<smiles>CCOC(=O)C(C)c1cccc(Oc2ccccc2)c1</smiles>

Fenoprofen<smiles>O=C(O)Cc1ccccc1Nc1cccc(C(F)(F)F)c1</smiles>

Flufenamic acid<smiles>Cc1c(Nc2ncccc2C(=O)O)cccc1C(F)(F)F</smiles>

Flunixin<smiles>COc1ccc2c(c1)C(CC(=O)O)C(C)N2C(=O)c1ccc(Cl)cc1</smiles>
Indomethacin<smiles>O=C(c1ccccc1)c1ccc2n1CCC2C(=O)O</smiles>

Ketorolac<smiles>COc1ccc2cc(CC(=O)O)ccc2c1</smiles>

6-MNA<smiles>CCCCC1C(=O)N(c2ccccc2)N(c2ccccc2)C1=O</smiles>

Phenylbutazone<smiles>CC(C(=O)O)c1ccc(N2Cc3ccccc3C2=O)cc1</smiles>

Indoprofen<smiles>Cc1ccc(Cl)c(Nc2ccccc2C(=O)O)c1Cl</smiles>

Meclofenamic acid<smiles>COc1ccc2cc(C(C)C(=O)O)ccc2c1</smiles>

Naproxen<smiles>Cc1ccc(C(=O)c2ccc(CC(=O)O)n2C)cc1</smiles>

Tolmetin<smiles>CC(C(=O)O)c1cccc(C(=O)c2ccccc2)c1</smiles>

Ketoprofen<smiles>Cc1cccc(Nc2ccccc2C(=O)O)c1C</smiles>

Mefenamic acid<smiles>CCCCC1C(=O)N(c2ccccc2)N(c2ccc(O)cc2)C1=O</smiles>

Oxyphenbutazone<smiles>Cc1cc(CC(=O)O)n(C)c1C(=O)c1ccc(Cl)cc1</smiles>

Zomepirac

Figure 1. Chemical structures of 16 NSAIDs.

stown, NJ, USA). Optima grade water was purchased from Honeywell Burdick \& Jackson (Muskegon, MI, USA) and methanol was from Fisher Scientific (Fair Lawn, NJ, USA). Acetonitrile (LC grade) and phosphoric acid were purchased from J.T. Baker (Phillipsburg, NJ, USA).

\subsection{Standard Solutions}

Each stock solution (10 mg/mL) was individually prepared in methanol, except fenoprofen, indoprofen and mefenamic acid for which $5.0 \mathrm{mg} / \mathrm{mL}$ standard solution was prepared using the dry powder. The stock solutions were stored at $-70^{\circ} \mathrm{C}$. A mixture of 16 NSAIDs at $100 \mu \mathrm{g} / \mathrm{mL}$ each was prepared by adding $100 \mu \mathrm{L}$ of each 10 $\mathrm{mg} / \mathrm{mL}$ stock solution, except fenoprofen, indoprofen and mefenamic acid for which $200 \mu \mathrm{L}$ of $5.0 \mathrm{mg} / \mathrm{mL}$ stock solution was added to $7900 \mathrm{uL}$ methanol to prepare $10 \mathrm{~mL}$ of the mixture. Working standard solutions of 0.1 , $0.2,0.4,1.0,1.5,2.0,3.0,4.0 \mu \mathrm{g} / \mathrm{mL}$ were prepared by serial dilution of $100 \mu \mathrm{g} / \mathrm{mL}$ of the solution mixture with methanol and stored at $-70^{\circ} \mathrm{C}$. Working $\mathrm{d}_{9}$-phenylbutazone $\left(\mathrm{IS}_{1}\right)$ solution $(1.0 \mu \mathrm{g} / \mathrm{mL})$ was prepared by diluting $0.05 \mathrm{~mL}$ stock solution $(200 \mu \mathrm{g} / \mathrm{mL})$ in $10 \mathrm{~mL}$ methanol. Working solution of clonixin $\left(1.0 \mathrm{ug} / \mathrm{mL}, \mathrm{IS}_{2}\right) \mathrm{was}$ prepared by serial dilution of $1.0 \mathrm{mg} / \mathrm{mL}$ stock solution using methanol.

Stock solution of ammonium acetate (1M) was prepared by dissolving $15.42 \mathrm{~g}$ ammonium acetate in $200 \mathrm{~mL}$ 
LC grade water. Ammonium acetate $(10 \mathrm{mM}$,) was prepared by adding $10 \mathrm{~mL} 1 \mathrm{M}$ stock solution to $990 \mathrm{~mL} \mathrm{LC}$ grade water. Phosphoric acid $\left(\mathrm{H}_{3} \mathrm{PO}_{4}\right)$ solution $(1 \mathrm{M})$ was prepared by adding $17 \mathrm{~mL}$ concentrated $\mathrm{H}_{3} \mathrm{PO}_{4}$ to 233 $\mathrm{mL}$ LC grade water to obtain $250 \mathrm{~mL} 1 \mathrm{M} \mathrm{H}_{3} \mathrm{PO}_{4}$ solution.

\subsection{Preparation of Calibration Samples}

Standard calibrators were prepared using pooled blank equine plasma samples that was previously demonstrated to be free of analytes using the present LC-MS/MS method. A $25 \mu \mathrm{L}$ aliquot of each working standard solution was added to $0.5 \mathrm{~mL}$ blank equine plasma to prepare 5.0, 10, 20, 50, 75, 100, 150, $200 \mathrm{ng} / \mathrm{mL}$ calibrators.

\subsection{Sample Preparation}

Plasma samples ( $0.5 \mathrm{~mL}$ aliquot each) were extracted using liquid-liquid extraction (LLE) with methyl tert-butyl ether (MTBE) for analyte recovery from plasma matrix. First, $10 \mu \mathrm{L}$ of $1.0 \mu \mathrm{g} / \mathrm{mL}$ each of IS solution was added to $0.5 \mathrm{~mL}$ plasma and mixed before $75 \mu \mathrm{L} \mathrm{H}_{3} \mathrm{PO}_{4}(1 \mathrm{M})$ was added to each sample and thoroughly mixed using a vortex device, then $5 \mathrm{~mL}$ MTBE was added to the tubes, capped and mixed on a rotorack for 10 min prior to centrifugation at $3000 \mathrm{rpm}(1610 \mathrm{x}$ g) for $10 \mathrm{~min}$. The resulting organic layer (top) was carefully transferred to a pre-labeled culture tube and the content was evaporated to dryness at $55^{\circ} \mathrm{C}$ (TechniDri-Block DB-3, Duxford, Cambridge, UK) under a steady stream of air or nitrogen. The dried extract was reconstituted in $100 \mu \mathrm{L}$ of $10 \mathrm{mM}$ ammonium acetate:acetonitrile $(90: 10, \mathrm{v} / \mathrm{v})$ mixture. The reconstituted extract was transferred into a 200 uL insert (Target PP Polyspring, National Scientific Company, Rockwood, TN, USA) from which $20 \mu \mathrm{L}$ was used for LC-MS/MS analysis.

\subsection{Liquid Chromatography-Mass Spectrometry}

An LC-MS system consisting of an Accela LC pump with on-line degasser, TSQ Quantum Ultra mass spectrometer (Thermo Fisher Scientific, San Jose, CA, USA) was used for analyte separation and mass analysis. Analyte separation was performed on an Ace $5 \mathrm{C}_{8}$ column $(2.1 \times 75 \mathrm{~mm}$ i.d., $5 \mu \mathrm{m}$ particle size $)$ with an $\mathrm{Ace}_{8}$ guard column (2.1 × $12.5 \mathrm{~mm})$ (MAC-MOD Analytical, Chadds Ford, PA, USA). Ammonium acetate (10 mM, solution A) with acetonitrile (solution B) was used as mobile phase in gradient programming (Table 1). Total analysis time was 9 min.

Mass spectrometer equipped with electrospray ionization (ESI) probe was operated in negative and positive ion modes. Electrospray ionization source parameters were optimized by injecting $1.0 \mu \mathrm{g} / \mathrm{mL} \mathrm{d}$-phenylbutazone with mobile phase $50 \%$ A and B mixture delivered at $200 \mu \mathrm{L} / \mathrm{min}$. The ESI source and MS parameters common to all analytes were as follows: ESI voltage, $3500 \mathrm{v}$; ion transfer capillary temperature, $325^{\circ} \mathrm{C}$; sheath gas, 60 arbitary units (AU); auxiliary gas, $10 \mathrm{AU}$; sweep cone gas, $0 \mathrm{AU}$; peak width relating to resolution (FWHM), 0.7 for Q1 and Q3; collision gas pressure, 1.5 mTorr; scan width $(\mathrm{m} / \mathrm{z})$, 0.5. Data acquisition and analysis were accomplished using Xcalibur software (v 2.0.5; Thermo Fisher Scientific). Data acquisition was conducted in selected-reaction monitoring (SRM) mode.

Table 1. LC gradient program for analysis of 16 NSAIDs.

\begin{tabular}{clll}
\hline Time (min.) & A\% & B\% & Flow rate $(\boldsymbol{\mu L} / \mathbf{m i n})$. \\
\hline 0.0 & 90.0 & 10.0 & 100 \\
2.0 & 50.0 & 50.0 & 200 \\
5.0 & 50.0 & 50.0 & 200 \\
5.5 & 20.0 & 80.0 & 200 \\
7.5 & 20.0 & 80.0 & 200 \\
8.0 & 90.0 & 10.0 & 200 \\
\hline
\end{tabular}

Mobile phase: $\mathrm{A}=10 \mathrm{mM}$ ammonium acetate; $\mathrm{B}$ = acetonitrile. 


\section{Results and Discussion}

\subsection{LC Chromatogram}

Due to the similarity in chemical structure and properties, complete separation of analytes solely by LC would take a long time to achieve. However, because mass spectrometry allows selection of analytes based on mass/ charge ratio for detection, well-resolved LC separation of the analytes in the present study was not necessary. Thus, the chromatographic conditions were optimized for short analysis time and generation of sharp peaks to provide high through-put and less false positive results. Liquid chromatography separation was performed in a gradient program using a $\mathrm{C}_{8}$ reversed-phase column with binary eluent solvents of $10 \mathrm{mM}$ ammonium acetate $\left(\mathrm{NH}_{4} \mathrm{OAc}\right.$ ) and acetonitrile (ACN) (Table 1). Representative LC-MS/SRM chromatograms of all analytes, IS $_{1}$ and $\mathrm{IS}_{2}$ spiked to control plasma sample are shown in Figure 2. Results showed that the LC gradient used in the present study generated sharp and symmetrical chromatographic peaks of the analytes with peak width of $\sim 0.2$ $0.3 \mathrm{~min}$ for each analyte. The retention times of all analytes in the study are listed in Table 2 . All analytes were eluted within 5 min of the total analysis time of 9 min.

\subsection{Mass Spectrometry Analysis}

Positive and negative ESI modes were applied to all analytes for ionization analysis and results obtained indicated that all analytes could be ionized in negative ESI mode whereas some could be in positive ESI mode. In view of the acidic characters of the analytes, the ionization efficiency in negative ESI mode was higher than that in positive ESI mode, resulting in stronger signal intensities. For this reason, negative ESI mode was used in this method for screening and quantification analyses. However, in negative ESI mode, not all analytes could be fragmented to generate, at least, three $\mathrm{MS}^{2}$ product ions for confirmation analysis. Thus, positive ionization mode
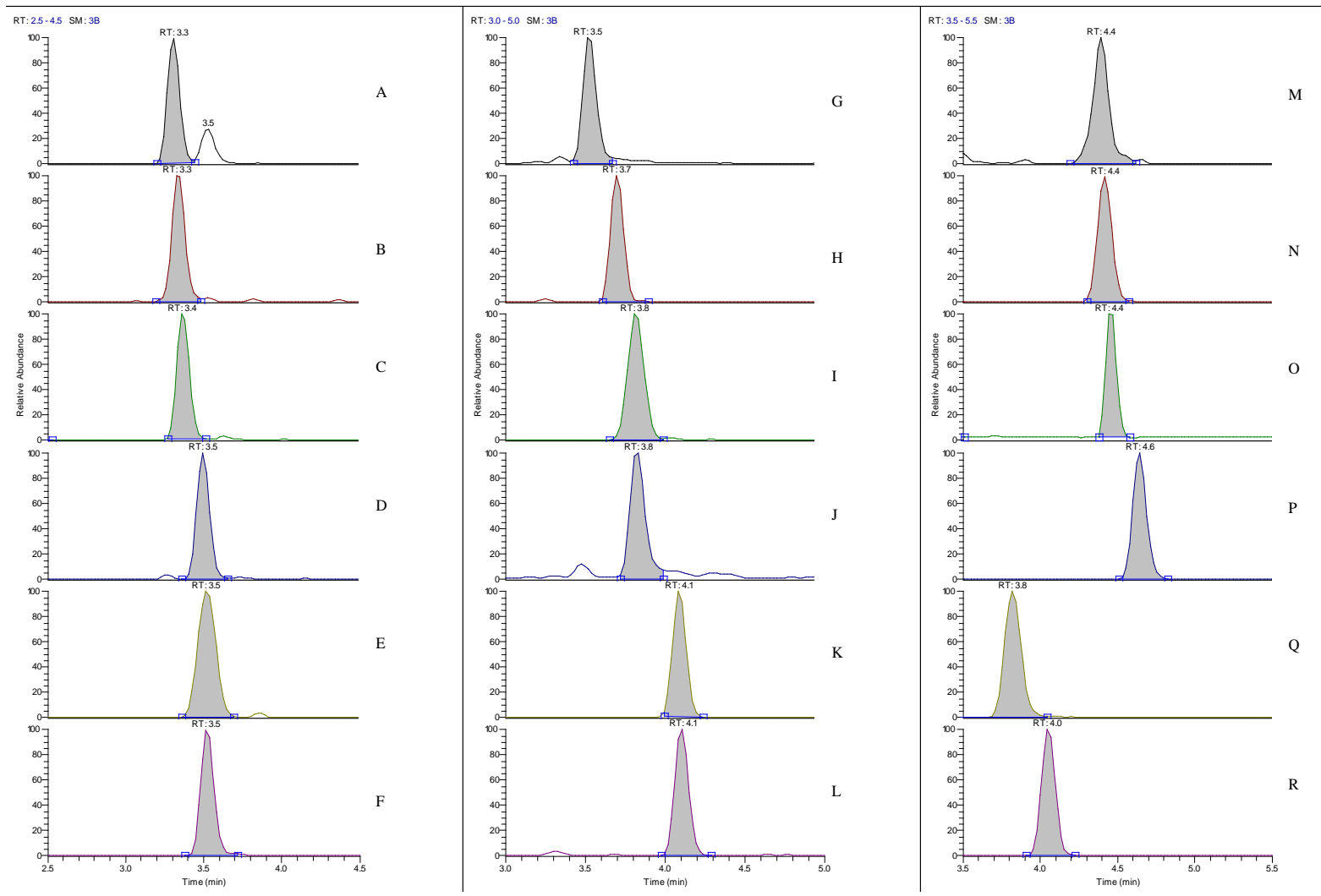

Figure 2. ESI(-) LC-MS/SRM chromatograms of 16 NSAIDs and two ISs (20 ng/mL) in equine plasma. A = ketorolac; B = indoprofen; $\mathrm{C}=6-\mathrm{MNA}$; $\mathrm{D}=$ tolmetin; $\mathrm{E}=$ oxyphenbutazone; $\mathrm{F}=$ naproxen; $\mathrm{G}=$ ketoprofen; $\mathrm{H}=$ zomepirac; $\mathrm{I}=$ phenylbutazone; $\mathrm{J}=$ fenoprofen; $\mathrm{K}$ = indomethacin; $\mathrm{L}=$ diclofenac; $\mathrm{M}=$ mefenamic acid; $\mathrm{N}$ = flunixin; $\mathrm{O}=$ meclofenamic acid; $\mathrm{P}=$ flufenamic acid; $\mathrm{Q}=\mathrm{d}_{9}$-phenylbutazone $\left(\mathrm{IS}_{1}\right) ; \mathrm{R}=\operatorname{clonixin}\left(\mathrm{IS}_{2}\right)$. 
Table 2. Retention time, precursor ion $[\mathrm{M}-\mathrm{H}]^{-}$, and SRM ion transitions for analysis of 16 NSAIDs.

\begin{tabular}{|c|c|c|c|c|}
\hline Analytes & Retention time & $\begin{array}{c}\mathrm{IM}_{(\mathrm{m} / \mathrm{z})}^{-} \\
\end{array}$ & $\begin{array}{c}\text { Ion transition }(\mathrm{m} / \mathrm{z}) \text { for } \\
\text { screening and quantification }\end{array}$ & $\begin{array}{c}\text { Ion transition } \\
(m / z) \text { for confirmation }\end{array}$ \\
\hline Diclofenac & 4.1 & 294 & $294 \rightarrow 250$ & $294 \rightarrow 250,214,294$ \\
\hline Fenoprofen & 3.8 & 241 & $241 \rightarrow 197$ & $241 \rightarrow 197,241,93$ \\
\hline Flufenamic acid & 4.6 & 280 & $280 \rightarrow 215$ & $280 \rightarrow 215,236,176$ \\
\hline Flunixin & 4.4 & 295 & $295 \rightarrow 251$ & $295 \rightarrow 251,211,209$ \\
\hline Indomethacin & 4.1 & 356 & $356 \rightarrow 312$ & $356 \rightarrow 312,297,282$ \\
\hline Indoprofen & 3.3 & 280 & $280 \rightarrow 236$ & $282^{\mathrm{a}} \rightarrow 236,218,77$ \\
\hline Ketoprofen & 3.5 & 253 & $253 \rightarrow 209$ & $255^{\mathrm{a}} \rightarrow 209,105,194$ \\
\hline Ketorolac & 3.3 & 254 & $254 \rightarrow 210$ & $256^{\mathrm{a}} \rightarrow 105,77,51$ \\
\hline Meclofenamic acid & 4.4 & 294 & $294 \rightarrow 258$ & $294 \rightarrow 258,214,294$ \\
\hline Mefenamic acid & 4.4 & 240 & $240 \rightarrow 196$ & $240 \rightarrow 196,92,240$ \\
\hline 6-MNA & 3.4 & 215 & $215 \rightarrow 156$ & $215 \rightarrow 156,215,171$ \\
\hline Naproxen & 3.5 & 229 & $229 \rightarrow 170$ & $229 \rightarrow 170,169,141$ \\
\hline Oxyphenbutazone & 3.5 & 323 & $323 \rightarrow 295$ & $323 \rightarrow 295,204,134$ \\
\hline Phenylbutazone & 3.8 & 307 & $307 \rightarrow 279$ & $307 \rightarrow 279,188,131$ \\
\hline Tolmetin & 3.5 & 256 & $256 \rightarrow 212$ & $258^{\mathrm{a}} \rightarrow 119,91,65$ \\
\hline Zomepirac & 3.7 & 290 & $290 \rightarrow 245$ & $292^{\mathrm{a}} \rightarrow 139,111,108$ \\
\hline D9-phenylbutazone (IS-1) & 3.8 & 316 & $316 \rightarrow 288$ & $316 \rightarrow 288$ \\
\hline Clonixin (IS-2) & 4.0 & 261 & $261 \rightarrow 217$ & $261 \rightarrow 217$ \\
\hline
\end{tabular}

${ }^{\mathrm{a}}$ Confirmation was conducted in positive ESI mode.

was also employed in this method for confirmation of some NSAIDs.

In negative ESI mode, the ionization source parameters were optimized for the highest signal intensity of $\mathrm{d}_{9}$-phenylbutazone. The $\mathrm{pH}$ of the LC mobile phase was $\sim 7.6$, which is $\sim 3-4$ units higher than the pKa of most of the analytes $(\mathrm{pKa}=\sim 3-4)$. Under the $\mathrm{pH}$ condition, analytes readily formed deprotonated molecules $[\mathrm{M}$ $\mathrm{H}]^{-}$which produced the highest signal intensity and, thus, were selected as precursor ions for collision-induced dissociation (CID) fragmentation analysis (Table 2). The full-scan product ion mass spectra of CID fragmentation analysis were evaluated and the most abundant or specific $\mathrm{MS}^{2}$ transitions of each analyte were monitored in SRM mode and applied to screening and quantification analyses. Under negative ESI mode, SRM transitions employed for screening and quantification analyses of 16 NSAIDs in the present study are summarized in Table 2.

Confirmation of the presence of a compound in a test sample is to demonstrate that the "chemical fingerprints" of the compound were the same as those of an authentic reference drug standard. In doping control analysis, confirmation of the presence of an unknown substance is the ultimate goal of the analysis. In mass spectrometry, the intensity ratio of several product ions from one precursor analyte is the "chemical fingerprint" of the specific analyte and is used as one of the criteria for confirmation. Guidance from the American Society for Mass Spectrometry in triple quadrupole mass spectrometry using SRM scan mode, suggests at least three SRM ion transitions must be obtained to determine ion intensity ratio for spectral comparison [25]. Based on sensitivity and specificity of the analytes exhibited in equine plasma matrix, the SRM transitions employed for confirmation analysis are listed in Table 2. In negative ESI mode, most analytes generated three SRM transitions for confirmation analysis except indoprofen, ketoprofen, ketorolac, tolmetin, and zomepirac. Due to the lack of SRM transitions in negative ESI mode for the above five NSAIDs, positive ESI mode was used for confirmation analysis of these NSAIDs and the results showed significant increase in sensitivity and specificity compared with negative ESI mode.

\subsection{Analyte Recovery and Matrix Effect}

Based on the acidic characters of NSAIDs ( $\mathrm{pK}_{\mathrm{a}}$ is $\sim 3-4$ ), at the $\mathrm{pH}$ of equine plasma ( $\mathrm{pH} \sim 7.0$ ), NSAIDs dis- 
sociate and present themselves in negative ion form, thus, their solubility in organic solvent is low, rendering extraction from plasma correspondingly low to difficult. To improve the extraction recovery, $\mathrm{H}_{3} \mathrm{PO}_{4}(1 \mathrm{M})$ was used to pre-treat equine plasma samples and lower the $\mathrm{pH}$, resulting in the analytes being present in their neutral non-ionic form which rendered them easily extractable into an organic solvent. In addition, under acidic $\mathrm{pH}$, NSAIDs such as phenylbutazone, oxyphenbutazone and tolmetin, which are significantly bound to plasma proteins [1]-[5], could be released by hydrolysis and render them readily extracted into an organic solvent. In the present study, results of $\mathrm{pH}$ determinations indicated that addition of $75 \mu \mathrm{L} \mathrm{H}_{3} \mathrm{PO}_{4}(1 \mathrm{M})$ to $0.5 \mathrm{~mL}$ equine plasma sample lowered plasma $\mathrm{pH}$ from 7 to 3 . Under such an acidic $\mathrm{pH}$ condition, analytes in the study were present in the neutral form and thus, were easily extracted into MTBE.

Different volumes of $1 \mathrm{M} \mathrm{H}_{3} \mathrm{PO}_{4}(0,75,150$ and $225 \mathrm{uL})$ were added to $50 \mathrm{ng} / \mathrm{mL}$ analyte-spiked plasma samples. The effect of adding varying volumes of $1 \mathrm{M} \mathrm{H}_{3} \mathrm{PO}_{4}$ into plasma on the extraction of analytes was evaluated using the relative recovery efficiency. The relative recovery efficiency was calculated using the following equation:

$$
\text { Relative recovery efficiency (\%) }=\mathrm{A}_{\text {treated }} / \mathrm{A}_{75 \mu \mathrm{L}} \times 100
$$

where $\mathrm{A}_{\text {treated }}$ was the chromatographic peak area of an analyte in plasma extracted by adding varying volumes of $1 \mathrm{M} \mathrm{H}_{3} \mathrm{PO}_{4}(0,75,150$ and $225 \mu \mathrm{L})$, and $\mathrm{A}_{75 \mu \mathrm{L}}$ was the chromatographic peak area of the same analyte in plasma extracted by adding $75 \mu \mathrm{L} 1 \mathrm{M} \mathrm{H}_{3} \mathrm{PO}_{4}$. Results obtained indicated that for most analytes, the relative recovery efficiency without $1 \mathrm{M} \mathrm{H}_{3} \mathrm{PO}_{4}$ treatment was $<100 \%$ (Table 3 ), suggesting that the extraction of analytes from the plasma without $\mathrm{H}_{3} \mathrm{PO}_{4}(1 \mathrm{M})$ was lower than that with $75 \mu \mathrm{L} 1 \mathrm{M} \mathrm{H}_{3} \mathrm{PO}_{4}$ (Table 3). However, for diclofenac, flufenamic acid, indomethacin, mefenamic acid and meclofenamic acid, the relative recovery efficiency without $1 \mathrm{M} \mathrm{H}_{3} \mathrm{PO}_{4}$ was $>100 \%$ (Table 3). This was not due to the fact that adding $1 \mathrm{M} \mathrm{H}_{3} \mathrm{PO}_{4}$ reduced the extraction of these analytes from plasma but due to the matrix effect which will be discussed later. The relative recovery efficiency for samples treated with $150 \mu \mathrm{L}$ and $225 \mathrm{uL} 1 \mathrm{M} \mathrm{H}_{3} \mathrm{PO}_{4}$ was close or less than $100 \%$ (Table 3), suggesting that $75 \mu \mathrm{L} 1 \mathrm{M} \mathrm{H}_{3} \mathrm{PO}_{4}$ achieved the maximum extraction recovery and that addition of more $1 \mathrm{M}$ $\mathrm{H}_{3} \mathrm{PO}_{4}$ did not improve the extraction of the analytes from equine plasma. Thus, in the present method, $75 \mu \mathrm{L}$ $1 \mathrm{M} \mathrm{H}_{3} \mathrm{PO}_{4}$ was used for pretreatment of samples prior to extraction in order to improve extraction recovery of the analytes.

Table 3. Relative recovery efficiency of 16 NSAIDs in varying volumes of $1 \mathrm{M}_{3} \mathrm{PO}_{4}$ treated equine plasma.

\begin{tabular}{|c|c|c|c|c|}
\hline Analytes & $\mathrm{No}_{3} \mathrm{PO}_{4}$ & $75 \mathrm{uL} \mathrm{H}_{3} \mathrm{PO}_{4}$ & $150 \mathrm{uL} \mathrm{H}_{3} \mathrm{PO}_{4}$ & $225 \mathrm{uL} \mathrm{H}_{3} \mathrm{PO}_{4}$ \\
\hline Diclofenac & 290.0 & 100.0 & 79.1 & 82.4 \\
\hline Fenoprofen & 50.0 & 100.0 & 85.1 & 85.8 \\
\hline Flufenamic acid & 1007.2 & 100.0 & 80.2 & 70.3 \\
\hline Flunixin & 37.8 & 100.0 & 87.5 & 90.2 \\
\hline Indomethacin & 185.3 & 100.0 & 84.0 & 82.3 \\
\hline Indoprofen & ND & 100.0 & 88.4 & 84.4 \\
\hline Ketoprofen & 20.2 & 100.0 & 81.1 & 75.0 \\
\hline Ketorolac & 3.3 & 100.0 & 84.4 & 77.5 \\
\hline Meclofenamic acid & 591.9 & 100.0 & 96.4 & 101.3 \\
\hline Mefenamic acid & 539.7 & 100.0 & 86.4 & 81.3 \\
\hline 6-MNA & 3.5 & 100.0 & 98.1 & 98.3 \\
\hline Naproxen & 5.3 & 100.0 & 87.1 & 85.6 \\
\hline Oxyphenbutazone & 40.4 & 100.0 & 95.1 & 93.5 \\
\hline Phenylbutazone & 90.9 & 100.0 & 102.7 & 98.2 \\
\hline Tolmetin & 5.2 & 100.0 & 77.3 & 64.3 \\
\hline Zomepirac & 9.7 & 100.0 & 73.5 & 54.5 \\
\hline
\end{tabular}

Relative recovery efficiency $(\%)=A_{\text {treated }} / A_{75 \mu L} \times 100$, where $A_{\text {treated }}$ is the chromatographic peak area of an analyte in equine plasma extracted by adding varying volumes of $1 \mathrm{M} \mathrm{H}_{3} \mathrm{PO}_{4}(0,75,150$ and $225 \mu \mathrm{L})$, and $\mathrm{A}_{75 \mu \mathrm{L}}$ is the chromatographic peak area of the same analyte in equine plasma extracted by adding $75 \mu \mathrm{L} 1 \mathrm{M} \mathrm{H}_{3} \mathrm{PO}_{4}$; $\mathrm{ND}=$ Not Detected. 
The absolute extraction recovery of NSAIDs treated with $75 \mu \mathrm{L} 1 \mathrm{M} \mathrm{H}_{3} \mathrm{PO}_{4}$ was determined by analyzing six different plasma samples spiked with analytes at concentrations of 10, 50, and $150 \mathrm{ng} / \mathrm{mL}$. Extraction recovery was calculated by comparison of the integrated chromatographic peak areas of analytes extracted from plasma samples with those of same analytes spiked in plasma extract. The extraction recovery was calculated as:

$$
\text { Extraction recovery }(\%)=A_{\text {processed }} / A_{\text {extract }} \times 100
$$

where $A_{\text {processed }}$ was the chromatographic peak area of analytes spiked in blank equine plasma and processed, and $\mathrm{A}_{\text {extract }}$ was the chromatographic peak area of analytes fortified in blank plasma extract. In this study, the average extraction recovery was from 45 to $99 \%$, with most of them higher than $70 \%$ (Table 4). Results suggested that MTBE was an efficient extraction solvent for the recovery of the analytes from acidified equine plasma.

\subsection{Matrix Effect}

Matrix effect on the analysis of the analytes in equine plasma is summarized in Table 5 . Negative and positive values indicated that plasma induced ion suppression or enhancement effects on the analytes, respectively. Most of the analytes showed negative values, suggesting that plasma induced ion suppression and the background interferences from plasma decreased signal intensity of the analytes under negative ESI mode. Ion suppression was extremely high (>-60\%) for diclofenac, indomethacin, mefenamic acid, meclofenamic acid and flufenamic acid. These significant ion suppression effects attributed to the results of $>100 \%$ relative recovery efficiencies discussed in previous section (Table 3). Addition of $1 \mathrm{M} \mathrm{H}_{3} \mathrm{PO}_{4}$ into plasma significantly increased the extraction of interfering substances from plasma and the interfering substances could suppress signal intensities of these NSAIDs, therefore, the chromatographic peak areas of NSAIDs in $\mathrm{H}_{3} \mathrm{PO}_{4}$-treated samples were smaller than those without $\mathrm{H}_{3} \mathrm{PO}_{4}$ treatment, resulting in the relative recovery efficiency in the sample without $\mathrm{H}_{3} \mathrm{PO}_{4}$ treatment $>100 \%$ for these NASIDS (Table 3 ).

It was interesting to note that for phenylbutazone and oxyphenbutazone, plasma contributed ion enhancement at a low concentration $(10 \mathrm{ng} / \mathrm{mL}$ ) but caused ion suppression at higher concentrations (50 and $150 \mathrm{ng} / \mathrm{mL}$ ) (Table 5). The reason for this phenomenon is unknown. In the present study, although equine plasma presents more or less matrix effect on NSAID analysis, it did not diminish the application of the present method to equine doping control analysis because the method still provides sensitive screening and reliable confirmation results.

Table 4. Extraction recovery of 16 NSAIDs $75 \mu \mathrm{L} 1 \mathrm{M} \mathrm{H}_{3} \mathrm{PO}_{4}$ treated equine plasma.

\begin{tabular}{|c|c|c|c|c|}
\hline Analytes & $10 \mathrm{ng} / \mathrm{mL}$ & $50 \mathrm{ng} / \mathrm{mL}$ & $150 \mathrm{ng} / \mathrm{mL}$ & Ave. \\
\hline Diclofenac & 71.3 & 61.1 & 65.9 & 66.1 \\
\hline Fenoprofen & 78.6 & 76.1 & 76.2 & 77.0 \\
\hline Flufenamic acid & 52.4 & 41.6 & 41.1 & 45.1 \\
\hline Flunixin & 90.6 & 82.0 & 91.6 & 88.1 \\
\hline Indomethacin & 72.0 & 73.4 & 75.0 & 73.5 \\
\hline Indoprofen & 88.0 & 77.3 & 90.3 & 85.2 \\
\hline Ketoprofen & 99.5 & 87.2 & 91.1 & 92.6 \\
\hline Ketorolac & 90.1 & 92.9 & 92.0 & 91.7 \\
\hline Meclofenamic acid & 52.1 & 47.2 & 46.7 & 48.7 \\
\hline Mefenamic acid & 60.3 & 50.3 & 48.2 & 52.9 \\
\hline 6-MNA & 95.2 & 92.9 & 95.9 & 94.7 \\
\hline Naproxen & 96.5 & 85.2 & 91.0 & 90.9 \\
\hline Oxyphenbutazone & 62.6 & 68.5 & 66.9 & 66.0 \\
\hline Phenylbutazone & 57.9 & 65.6 & 61.5 & 61.6 \\
\hline Tolmetin & 100.4 & 101.4 & 96.0 & 99.3 \\
\hline Zomepirac & 95.7 & 97.8 & 92.0 & 95.1 \\
\hline
\end{tabular}

Extraction recovery $(\%)=A_{\text {processed }} / A_{\text {extract }} \times 100$, where $A_{\text {processed }}$ is the chromatographic peak area of analyte spiked in blank equine plasma and processed, and $\mathrm{A}_{\text {extract }}$ is that of analyte fortified blank equine plasma extract. 
Table 5. Matrix effect of equine plasma in the analysis of 16 NSAIDs.

\begin{tabular}{cccc}
\hline Analytes & $\mathbf{1 0 ~ n g / m L}$ & $\mathbf{5 0 ~ n g} / \mathbf{m L}$ & $\mathbf{1 5 0} \mathbf{~ n g} \mathbf{m L}$ \\
\hline Diclofenac & -69.0 & -69.9 & -72.1 \\
Fenoprofen & -35.2 & -37.2 & -38.1 \\
Flufenamic acid & -83.7 & -86.4 & -86.2 \\
Flunixin & -8.9 & -16.6 & -17.5 \\
Indomethacin & -60.6 & -62.9 & -62.4 \\
Indoprofen & -12.5 & -6.8 & -2.5 \\
Ketoprofen & -1.3 & -10.0 & -11.8 \\
Ketorolac & -3.9 & -16.0 & -13.3 \\
Meclofenamic acid & -75.7 & -80.8 & -81.8 \\
Mefenamic acid & -76.0 & -78.0 & -77.7 \\
6-MNA & -32.0 & -35.9 & -36.4 \\
Naproxen & -37.7 & -37.3 & -41.3 \\
Oxyphenbutazone & 145.5 & -3.0 & -15.5 \\
Phenylbutazone & 101.3 & -17.9 & -33.3 \\
Tolmetin & -14.2 & -29.5 & -21.9 \\
Zomepirac & -30.0 & -44.7 & -41.2 \\
\hline
\end{tabular}

Matrix effect (ion suppression or enhancement \%) $=\left(A_{\text {extract }}-A_{\text {solvent }}\right) / A_{\text {solvent }} \times 100$, where $A_{\text {solvent }}$ is the chromatographic peak area of an analyte spiked in extraction solvent, and $\mathrm{A}_{\text {extract }}$ is the chromatographic peak area of same analyte spiked in blank equine plasma extract.

\subsection{Specificity}

In doping control analysis, a method with high specificity is required to avoid false positives during screening analysis, thereby reducing the workload of performing further confirmation analysis. In the present study, ion transitions with high specificity were selected for screening analysis (Table 2). Chromatograms of blank plasma and those of blank plasma spiked with $5.0 \mathrm{ng} / \mathrm{mL}$ analytes (limit of quantification) are shown in Figure 3. Direct interference in the blank plasma caused by endogenous substances at the retention time of analytes was not observed except for ketoprofen (3.5 min; Figure 3(G)), suggesting that the LLE procedure used yielded sufficiently clean extracts and that the liquid chromatography elution gradient used separated endogenous interferences from the analytes. Results indicated that the present method demonstrated high specificity for the analysis of the 16 NSAIDs in equine plasma.

For ketoprofen, equine plasma had an interference peak at the retention time of 3.5 min (Figure 3(G), column 2), which was the same as that of ketoprofen (Figure 3(G), column 2). Since no other SRM transition could be selected for ketoprofen analysis in negative ESI mode to improve specificity, a threshold of $5.0 \mathrm{ng} / \mathrm{mL}$ was established for screening for ketoprofen, i.e. the chromatographic peak detected in a racehorse plasma sample with signal intensity higher than that of ketoprofen in $5.0 \mathrm{ng} / \mathrm{mL}$ calibration standard sample was considered a ketoprofen positive suspect and the sample was submitted for confirmation analysis. Any sample with peak intensity less than $5.0 \mathrm{ng} / \mathrm{mL}$ calibration standard was considered negative for ketoprofen. Analysis for ketoprofen confirmation was achieved in positive ESI mode, thus, the interference from plasma in negative ESI mode did not affect confirmation results since interference was not observed in positive ESI mode.

\subsection{Sensitivity and Linearity}

The limit of detection (LOD), quantification (LOQ) and confirmation (LOC) are listed in Table 6. The LOD was $1.0-5.0 \mathrm{ng} / \mathrm{mL}$, with most of the analytes detected at $1.0 \mathrm{ng} / \mathrm{mL}$. In the present method, to minimize sample usage, the sample volume used for analysis was only $0.5 \mathrm{~mL}$. In the case of $1.0 \mathrm{~mL}$ sample aliquot used, the signal intensity of analyte would be stronger and the LOD could be lower than current level. The LOQ was 1.0 $5.0 \mathrm{ng} / \mathrm{mL}$ for all analytes. The ratio of peak area of the analyte to that of IS was proportional to concentration of the analyte from $5.0-200 \mathrm{ng} / \mathrm{mL}$. Linear regression model with $1 / \mathrm{x}$ weighting factor was used in describing the 

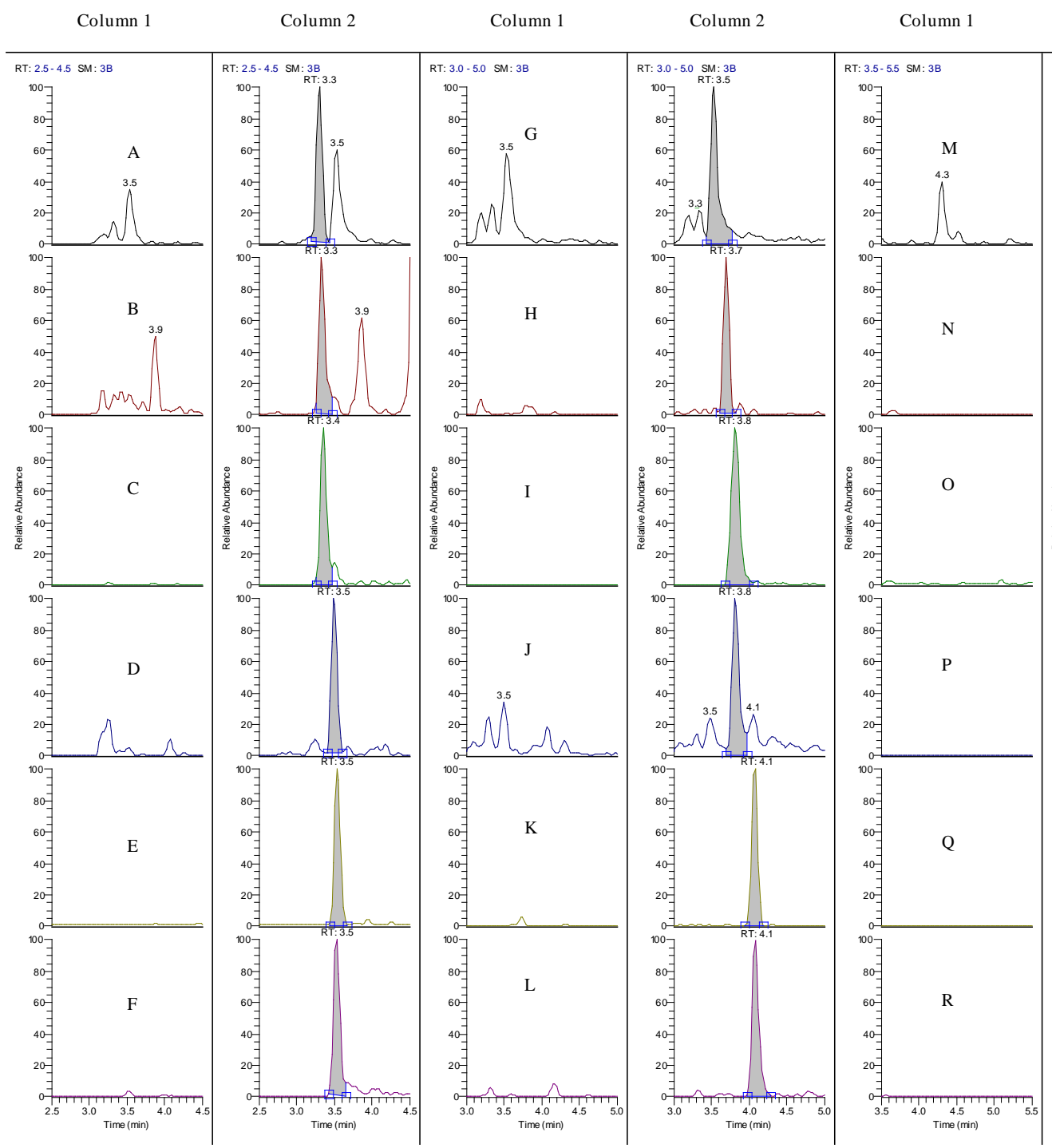

Column 2

Figure 3. ESI(-) LC-MS/SRM chromatograms of 16 NSAIDs and two internal standards indicating method specificity. Column 1 is blank plasma and column 2 is corresponding analyte spiked in blank plasma $(5.0 \mathrm{ng} / \mathrm{mL})$. $\mathrm{A}=\mathrm{ketorolac}$; $\mathrm{B}=$ indoprofen; $\mathrm{C}$ = 6-MNA; $\mathrm{D}$ = tolmetin; $\mathrm{E}$ = oxyphenbutazone; $\mathrm{F}$ = naproxen; $\mathrm{G}$ = ketoprofen; $\mathrm{H}$ = zomepirac; $\mathrm{I}=$ phenylbutazone; $\mathrm{J}$ = fenoprofen; $\mathrm{K}$ = indomethacin; $\mathrm{L}$ = diclofenac; $\mathrm{M}=$ mefenamic acid; $\mathrm{N}$ = flunixin; $\mathrm{O}$ = meclofenamic acid; $\mathrm{P}=$ flufenamic acid; $\mathrm{Q}=\mathrm{d}_{9}$-phenylbutazone $\left(\mathrm{IS}_{1}\right) ; \mathrm{R}=\operatorname{clonixin}\left(\mathrm{IS}_{2}\right)$.

regression relationship. The average coefficient of determination $\left(r^{2}\right)$ was $>0.97$. LOC was the lowest concentration at which the product ion intensities were sufficiently strong to produce stable ion intensity ratio for analyte confirmation, and it was 1.0 - $20 \mathrm{ng} / \mathrm{mL}$, depending on the analyte (Table 6).

\subsection{Accuracy and Precision}

For quantification analysis, the method accuracy and precision were validated. The intra-day accuracy and precision were determined by analyzing twenty four validation samples at four concentrations (5.0, 10, 50 and 150 $\mathrm{ng} / \mathrm{mL} ; \mathrm{n}=6$ each) and six replicates in one batch in a day. Inter-day accuracy and precision were determined in three consecutive batches in three separate days with the same concentration and replicates. The concentrations of 5.0, 10, 50 and $150 \mathrm{ng} / \mathrm{mL}$ used for determining accuracy and precision corresponded to lower limit of quantification (LLOQ), low, medium and high concentrations used in the calibration curves. Accuracy (bias \%) was determined by the agreement between the concentrations of analytes determined and those spiked into blank 
Table 6. Limit of detection, quantification, confirmation of 16 NSAIDs in equine plasma.

\begin{tabular}{cccc}
\hline Analytes & LOD & LOQ & LOC \\
\hline Diclofenac & 1.0 & 1.0 & 1.0 \\
Fenoprofen & 2.5 & 5.0 & 20 \\
Flufenamic acid & 1.0 & 2.5 & 2.5 \\
Flunixin & 1.0 & 1.0 & 1.0 \\
Indomethacin & 1.0 & 1.0 & 2.5 \\
Indoprofen & 1.0 & 2.5 & 5.0 \\
Ketoprofen & 1.0 & 5.0 & 5.0 \\
Ketorolac & 1.0 & 1.0 & 5.0 \\
Meclofenamic acid & 1.0 & 5.0 & 5.0 \\
Mefenamic acid & 2.5 & 5.0 & 20 \\
6-MNA & 1.0 & 1.0 & 1.0 \\
Naproxen & 1.0 & 1.0 & 5.0 \\
Oxyphenbutazone & 1.0 & 2.5 & 2.5 \\
Phenylbutazone & 1.0 & 1.0 & 1.0 \\
Tolmetin & 5.0 & 2.5 & 2.5 \\
Zomepirac & 2.5 & 2.5 & \\
\hline
\end{tabular}

$\mathrm{LOD}=$ limit of detection; $\mathrm{LOQ}=$ limit of quantification; $\mathrm{LOC}=$ limit of confirmation.

plasma. Precision (RSD \%) of the assay was expressed as a percent of the standard deviation divided by the mean of determined concentrations. The Accuracy and precision study results are presented in Table 7. Results obtained indicated that the method could be used for accurate quantification of diclofenac, fenoprofen, flunixin, indomethacin, indoprofen, ketoprofen, ketorolac, 6-MNA, naproxen, phenylbutazone, oxyphenbutazone and zomepirac with accurate acceptance limit of $\pm 20 \%$ of the theoretical values, and RSD around the mean value did not exceed $\pm 20 \%$ at the four concentrations validated (Table 7). However, for flufenamic acid, mefenamic acid, meclofenamic acid and tolmetin, either accuracy or precision were beyond the acceptance limit of $\pm 20 \%$ (Table 7). For these analytes, the method provides only semi-quantitative results.

\subsection{Confirmation of the Presence of Analyte in a Test Sample}

In equine doping control analysis, confirmation of the presence of an unknown substance in a racehorse plasma sample is the ultimate goal by using LC-MS/MS technology. A match of the chromatographic retention time $\left(\mathrm{t}_{\mathrm{R}}\right)$ and mass spectrum of the test sample with those of the reference drug standard must be established to confirm the presence of an unknown substance in a sample. In the present method, retention time match was defined as the retention time of a suspect analyte in a racehorse plasma sample in the range of $\pm 0.2 \mathrm{~min}$ of the average retention time of the same analyte in standard calibrator samples. The match of mass spectrum was achieved by comparing the product ion ratio between a suspect sample and calibration standard samples using ion ratio similarity [5]. Criteria for confirmation of the presence of an analyte in equine plasma were defined as the similarity in ion intensity ratio between unknown samples and the authentic drug standard which must be within $80 \%$ $120 \%$ [5].

In the present method, three SRM ion transitions for each analyte were obtained to determine ion intensity ratio similarity for spectral comparison [5]. In negative ESI mode, most analytes, except indoprofen, ketoprofen, ketorolac, tolmetin, and zomepirac, generated three SRM ion transitions for ion intensity ratio similarity calculation. For these five analytes, positive ESI mode was evaluated and the results indicated that indoprofen, ketoprofen, ketorolac, tolmetin and zomepirac were readily ionized and fragmented in positive ESI mode to generate three product ions for confirmation analysis. Significant improvement in sensitivity was achieved in positive ESI mode for these five analytes, compared with negative ESI mode. Thus, for indoprofen, ketoprofen, ketorolac, tolmetin and zomepirac, confirmation analysis was conducted in positive ESI mode. The SRM transitions in both positive and negative ESI modes for confirmation analysis of the five analytes are listed in Table 2. 
Table 7. Intra-day and inter-day precision and accuracy for quantification of 16 NSAIDs in equine plasma.

\begin{tabular}{|c|c|c|c|c|c|c|c|}
\hline \multirow[b]{2}{*}{ Analytes } & \multirow[b]{2}{*}{$\begin{array}{c}\text { Conc. spiked } \\
\text { (ng/mL) }\end{array}$} & \multicolumn{3}{|c|}{ Intra-day $(n=6)$} & \multicolumn{3}{|c|}{ Inter-day $(n=6)$} \\
\hline & & $\begin{array}{l}\text { Conc. measured } \\
(\mathrm{mean} \pm \mathrm{SD}) \\
(\mu \mathrm{g} / \mathrm{mL})\end{array}$ & Precision (\%) & $\begin{array}{c}\text { Accuracy } \\
\text { (\%) }\end{array}$ & $\begin{array}{l}\text { Conc. measured } \\
(\mathrm{mean} \pm \mathrm{SD}) \\
(\mu \mathrm{g} / \mathrm{mL})\end{array}$ & $\begin{array}{c}\text { Precision } \\
(\%)\end{array}$ & $\begin{array}{c}\text { Accuracy } \\
\text { (\%) }\end{array}$ \\
\hline \multirow{4}{*}{ Diclofenac } & 5 & $4.3 \pm 0.6$ & 13.2 & 86.7 & $4.9 \pm 0.8$ & 16.9 & 98.6 \\
\hline & 10 & $8.6 \pm 0.7$ & 8.2 & 86.2 & $9.3 \pm 1.0$ & 11.0 & 93.0 \\
\hline & 50 & $51.2 \pm 6.0$ & 11.7 & 102.4 & $48.2 \pm 6.4$ & 13.4 & 96.4 \\
\hline & 150 & $139.7 \pm 23.0$ & 16.5 & 93.1 & $130.5 \pm 18.3$ & 14.1 & 87.0 \\
\hline \multirow{5}{*}{ Fenoprofen } & 5 & $5.9 \pm 0.2$ & 4.1 & 117.0 & $4.7 \pm 0.9$ & 19.8 & 94.2 \\
\hline & 10 & $9.8 \pm 0.6$ & 6.0 & 98.1 & $9.4 \pm 0.4$ & 4.7 & 93.7 \\
\hline & 50 & $52.8 \pm 3.2$ & 6.1 & 105.6 & $47.9 \pm 4.5$ & 9.4 & 95.8 \\
\hline & 150 & $146.4 \pm 14.3$ & 9.8 & 97.6 & $133.2 \pm 8.7$ & 6.6 & 88.8 \\
\hline & 5 & $4.4 \pm 0.9$ & 21.1 & 87.1 & $4.4 \pm 1.1$ & 24.7 & 88.5 \\
\hline \multirow{3}{*}{ Flufenamic acid } & 10 & $5.5 \pm 1.3$ & 24.5 & 54.6 & $8.1 \pm 2.5$ & 30.4 & 80.9 \\
\hline & 50 & $43.0 \pm 7.5$ & 17.5 & 85.9 & $46.9 \pm 8.7$ & 18.5 & 93.8 \\
\hline & 150 & $102.7 \pm 40.0$ & 38.9 & 68.5 & $112.8 \pm 37.0$ & 32.8 & 75.2 \\
\hline \multirow{4}{*}{ Flunixin } & 5 & $5.0 \pm 0.3$ & 6.4 & 100.5 & $5.2 \pm 0.6$ & 11.0 & 104.7 \\
\hline & 10 & $10.3 \pm 0.9$ & 9.0 & 103.4 & $11.0 \pm 1.0$ & 9.3 & 110.2 \\
\hline & 50 & $52.4 \pm 2.4$ & 4.7 & 104.9 & $52.5 \pm 4.2$ & 8.1 & 104.9 \\
\hline & 150 & $145.9 \pm 15.0$ & 10.3 & 97.3 & $142.7 \pm 13.3$ & 9.4 & 95.1 \\
\hline \multirow{4}{*}{ Indomethacin } & 5 & $4.5 \pm 0.6$ & 13.6 & 90.2 & $4.8 \pm 0.8$ & 16.9 & 95.9 \\
\hline & 10 & $8.5 \pm 0.6$ & 7.2 & 84.8 & $8.9 \pm 0.4$ & 4.8 & 88.7 \\
\hline & 50 & $49.0 \pm 5.4$ & 11.1 & 98.0 & $47.6 \pm 7.8$ & 16.3 & 95.3 \\
\hline & 150 & $130.1 \pm 20.3$ & 15.6 & 86.8 & $129.5 \pm 21.5$ & 16.6 & 86.4 \\
\hline \multirow{4}{*}{ Indoprofen } & 5 & $5.1 \pm 0.4$ & 7.1 & 101.1 & $5.1 \pm 0.2$ & 4.5 & 101.9 \\
\hline & 10 & $10.3 \pm 0.5$ & 4.8 & 102.6 & $10.4 \pm 0.9$ & 8.4 & 103.8 \\
\hline & 50 & $50.6 \pm 2.4$ & 4.8 & 101.2 & $53.1 \pm 5.0$ & 9.5 & 106.2 \\
\hline & 150 & $146.1 \pm 7.9$ & 5.4 & 97.4 & $143.9 \pm 9.2$ & 6.4 & 95.9 \\
\hline \multirow{4}{*}{ Ketoprofen } & 5 & $5.2 \pm 1.4$ & 27.3 & 103.3 & $5.1 \pm 0.8$ & 14.9 & 102.1 \\
\hline & 10 & $9.9 \pm 1.0$ & 10.2 & 99.2 & $10.1 \pm 0.9$ & 8.4 & 101.4 \\
\hline & 50 & $50.5 \pm 2.0$ & 4.0 & 101.1 & $50.0 \pm 3.7$ & 7.3 & 100.0 \\
\hline & 150 & $140.6 \pm 9.1$ & 6.5 & 93.7 & $141.2 \pm 11.7$ & 8.3 & 94.2 \\
\hline \multirow{4}{*}{ Ketorolac } & 5 & $4.6 \pm 0.2$ & 3.9 & 92.3 & $5.0 \pm 0.7$ & 13.6 & 100.5 \\
\hline & 10 & $9.8 \pm 0.7$ & 7.2 & 98.0 & $10.0 \pm 0.4$ & 4.4 & 99.7 \\
\hline & 50 & $46.4 \pm 4.9$ & 10.5 & 92.8 & $47.3 \pm 5.8$ & 12.3 & 94.5 \\
\hline & 150 & $139.8 \pm 4.4$ & 3.1 & 93.2 & $146.8 \pm 12.5$ & 8.5 & 97.9 \\
\hline
\end{tabular}




\begin{tabular}{|c|c|c|c|c|c|c|c|}
\hline \multicolumn{8}{|l|}{ Continued } \\
\hline \multirow{4}{*}{ Meclofenamic acid } & 5 & $4.2 \pm 1.7$ & 40.8 & 84.8 & $3.2 \pm 1.0$ & 32.1 & 63.0 \\
\hline & 10 & $5.4 \pm 1.9$ & 35.6 & 53.7 & $6.7 \pm 2.7$ & 40.2 & 67.2 \\
\hline & 50 & $35.0 \pm 7.4$ & 21.0 & 70.0 & $46.9 \pm 12.7$ & 27.2 & 93.8 \\
\hline & 150 & $80.0 \pm 36.2$ & 45.3 & 53.3 & $98.3 \pm 34.4$ & 35.0 & 65.5 \\
\hline \multirow{4}{*}{ Mefenamic acid } & 5 & $4.1 \pm 0.5$ & 11.9 & 81.2 & $3.8 \pm 0.3$ & 8.9 & 75.0 \\
\hline & 10 & $6.0 \pm 1.2$ & 20.4 & 59.6 & $7.8 \pm 1.9$ & 24.5 & 78.0 \\
\hline & 50 & $37.0 \pm 6.8$ & 18.4 & 74.0 & $44.7 \pm 8.4$ & 18.8 & 89.4 \\
\hline & 150 & $92.8 \pm 36.1$ & 38.8 & 61.9 & $103.6 \pm 30.2$ & 29.1 & 69.1 \\
\hline \multirow{4}{*}{ 6-MNA } & 5 & $4.5 \pm 0.6$ & 13.0 & 90.4 & $4.6 \pm 0.4$ & 8.8 & 92.1 \\
\hline & 10 & $10.3 \pm 0.5$ & 5.1 & 103.0 & $10.1 \pm 0.3$ & 2.9 & 101.2 \\
\hline & 50 & $55.6 \pm 3.8$ & 6.8 & 111.3 & $52.2 \pm 7.7$ & 14.7 & 104.4 \\
\hline & 150 & $167.2 \pm 10.3$ & 6.2 & 111.5 & $156.7 \pm 17.4$ & 11.1 & 104.4 \\
\hline \multirow{4}{*}{ Naproxen } & 5 & $4.9 \pm 0.3$ & 6.4 & 96.9 & $4.7 \pm 0.3$ & 6.6 & 94.2 \\
\hline & 10 & $10.6 \pm 1.0$ & 9.0 & 105.5 & $9.8 \pm 0.4$ & 4.1 & 97.8 \\
\hline & 50 & $58.6 \pm 4.1$ & 6.9 & 117.1 & $53.4 \pm 5.5$ & 10.4 & 106.9 \\
\hline & 150 & $165.3 \pm 12.5$ & 7.6 & 110.2 & $152.4 \pm 10.4$ & 6.8 & 101.6 \\
\hline \multirow{4}{*}{ Oxyphenbutazone } & 5 & $4.9 \pm 0.6$ & 13.1 & 97.1 & $5.4 \pm 0.7$ & 13.2 & 108.3 \\
\hline & 10 & $9.4 \pm 0.8$ & 8.1 & 93.5 & $9.7 \pm 1.2$ & 12.4 & 96.5 \\
\hline & 50 & $40.6 \pm 2.2$ & 5.4 & 81.3 & $45.1 \pm 3.8$ & 8.5 & 90.2 \\
\hline & 150 & $130.7 \pm 15.0$ & 11.5 & 87.2 & $143.8 \pm 18.1$ & 12.6 & 95.9 \\
\hline \multirow{4}{*}{ Phenylbutazone } & 5 & $5.6 \pm 0.5$ & 9.7 & 112.8 & $6.0 \pm 1.0$ & 15.8 & 120.3 \\
\hline & 10 & $10.2 \pm 0.8$ & 7.9 & 102.3 & $10.3 \pm 1.0$ & 9.4 & 102.7 \\
\hline & 50 & $48.0 \pm 1.6$ & 3.4 & 96.0 & $51.1 \pm 3.2$ & 6.3 & 102.3 \\
\hline & 150 & $143.7 \pm 8.9$ & 6.2 & 95.8 & $149.8 \pm 11.0$ & 7.4 & 99.9 \\
\hline \multirow{4}{*}{ Tolmetin } & 5 & $4.0 \pm 0.8$ & 16.9 & 79.8 & $4.8 \pm 1.5$ & 30.9 & 95.3 \\
\hline & 10 & $7.8 \pm 1.1$ & 14.7 & 77.7 & $8.4 \pm 2.0$ & 23.7 & 83.9 \\
\hline & 50 & $40.68 \pm 3.9$ & 9.6 & 81.4 & $44.0 \pm 6.6$ & 15.0 & 88.0 \\
\hline & 150 & $121.53 \pm 6.0$ & 5.0 & 81.0 & $132.9 \pm 20.3$ & 15.3 & 88.6 \\
\hline \multirow{4}{*}{ Zomepirac } & 5 & $4.5 \pm 1.0$ & 21.8 & 90.3 & $4.5 \pm 1.1$ & 25.6 & 89.3 \\
\hline & 10 & $8.2 \pm 1.0$ & 12.4 & 82.0 & $8.9 \pm 1.9$ & 21.9 & 88.6 \\
\hline & 50 & $40.2 \pm 5.8$ & 14.4 & 80.5 & $48.1 \pm 11.3$ & 23.6 & 96.1 \\
\hline & 150 & $122.1 \pm 13.4$ & 11.0 & 81.4 & $136.5 \pm 41.0$ & 30.0 & 91.0 \\
\hline
\end{tabular}

Precision $=$ Standard deviation of conc. measured/conc. measured $\times 100$; Accuracy $=$ Conc. measured $/$ conc. spiked $\times 100$.

The method described in this study is routinely employed in screening and confirmation of the presence of NSAIDs in plasma samples collected from racehorses post competition in PA. A representative naproxen positive case is shown in Figure 4. Results indicated that in blank plasma (Figure 4(A)), no chromatographic peak of naproxen was detected. The retention time of the chromatographic peak detected in a racehorse sample (Figure 4(B)) matched that of an authentic naproxen reference standard sample at $t_{R}$ of 3.6 min (Figure 4(C)). 


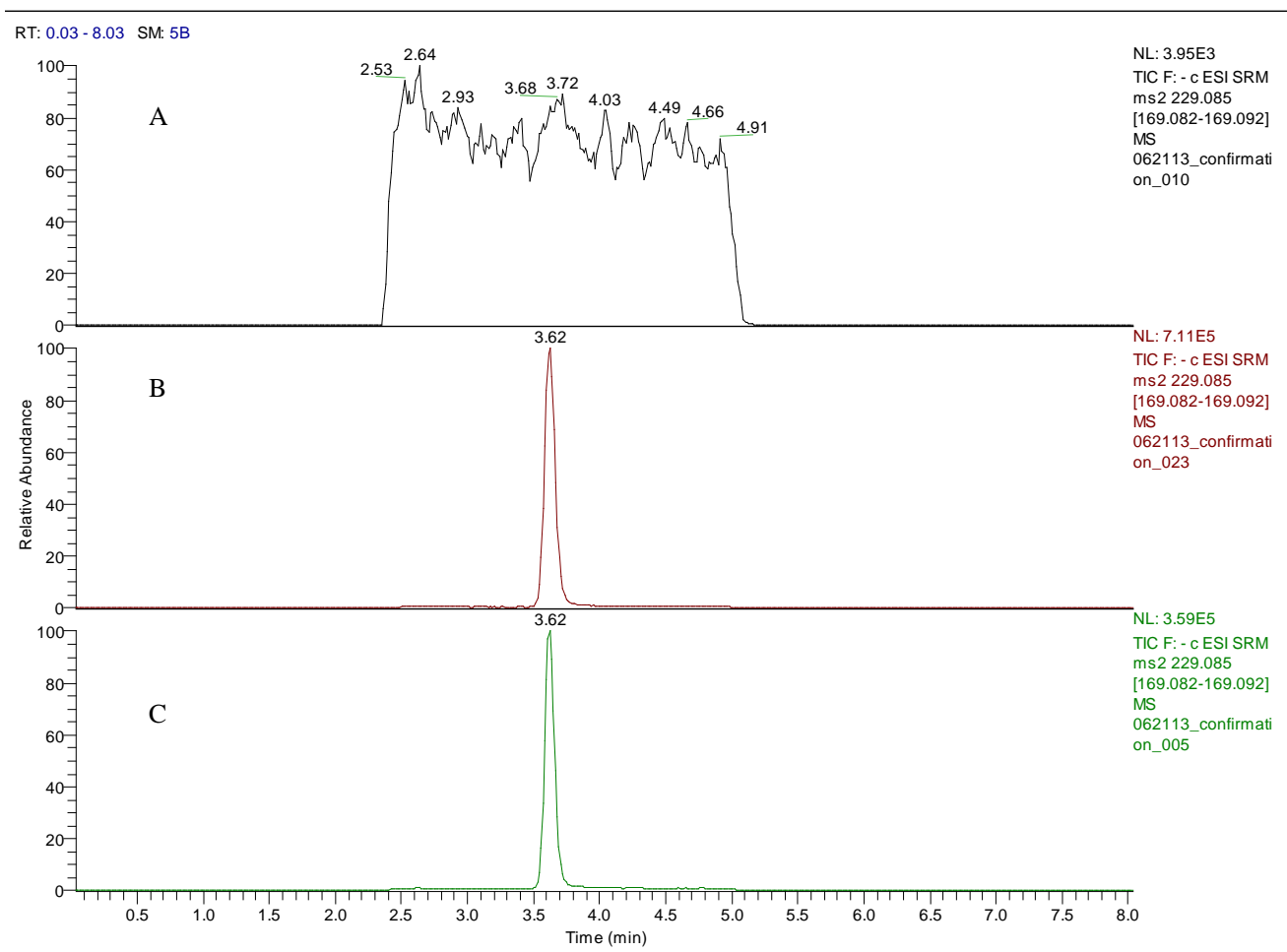

Figure 4. A naproxen positive LC chromatogram comparison. A = blank plasma; $\mathrm{B}=$ post competition plasma sample suspected of containing naproxen; $C=50 \mathrm{ng} / \mathrm{mL}$ naproxen spiked in blank plasma. The chromatograms (B and $\mathrm{C}$ ) show that the retention time (3.62 $\mathrm{min})$ of the suspect naproxen chromatographic peak in B matched that of an authentic naproxen reference standard in blank plasma sample (C).

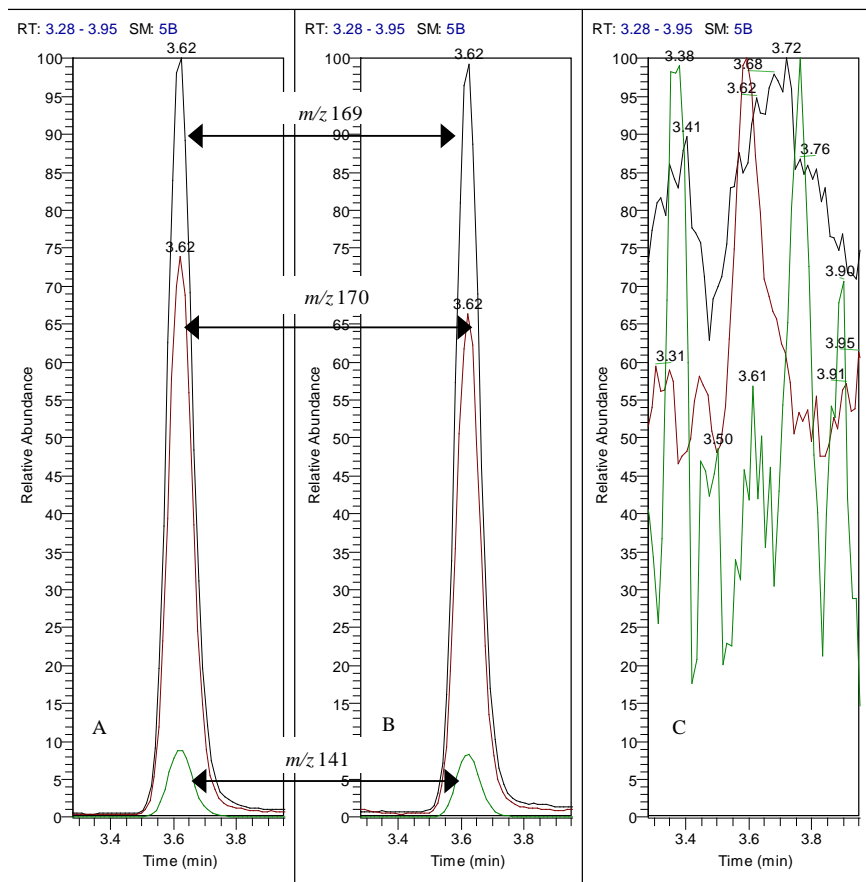

Figure 5. Naproxen positive product ion intensity comparison graph. A = racehorse plasma sample with naproxen detected; $\mathrm{B}=50 \mathrm{ng} / \mathrm{mL}$ naproxen spiked in blank plasma; $\mathrm{C}=$ blank plasma. The product ion intensity comparison graph shows that the ion ratios of product ions $(\mathrm{m} / \mathrm{z} 169, \mathrm{~m} / \mathrm{z} 170$ and $\mathrm{m} / \mathrm{z} 141)$ detected in racehorse plasma sample matched those of an authentic naproxen spiked standard sample (see ion ratio similarity in Table 8). 
Table 8. Product ion ratio comparison for confirmation of naproxen in post-race equine plasma sample.

\begin{tabular}{ccccc}
\hline Analyte & Product Ions & $\begin{array}{c}\text { Ion intensity ratio of standard } \\
\text { sample }(\mathbf{n}=\mathbf{2 2})\end{array}$ & $\begin{array}{c}\text { Ion intensity ratio of } \\
\text { unknown sample }(\mathbf{n}=\mathbf{4})\end{array}$ & $\begin{array}{c}\text { Ion ratio similarity }^{\mathbf{b}} \\
(\mathbf{\%})\end{array}$ \\
\hline Naproxen & 170 & $69.4 \pm 2.3$ & $72.9 \pm 3.0$ & 95.2 \\
& 141 & $8.8 \pm 0.8$ & $8.8 \pm 0.3$ & 100.0 \\
& 169 & $100.0^{\mathrm{a}}$ & 100.0 & N/A \\
\hline
\end{tabular}

${ }^{\mathrm{a}}$ Product ion with the largest intensity was used as the denominator in calculating ion intensity ratio. ${ }^{\mathrm{b}}$ Ion ratio similarity $(\%)=$ Ion intensity ratio of unknown sample/Ion intensity ratio of standard drug spiked in equine control plasma $\times 100$.

Ion ratio comparison graph (Figure 5) shows the three product ions $(\mathrm{m} / \mathrm{z} 170,169$, and 141 at the same retention time of $3.6 \mathrm{~min}$ ) that were detected in a racehorse sample and the ion ratios of the analyte in the racehorse plasma sample collected post-race matched those of an authentic naproxen standard spiked in blank equine plasma sample and similarly analyzed. The ion ratio similarity was within $20 \%$ range (Table 8). Thus, the presence of naproxen was confirmed in a plasma sample collected from a racehorse post competition in PA.

\section{Conclusion}

This method was developed for the analysis of 16 NSAIDs which are commonly used in treating racehorses with inflammation, soreness and related conditions. The method satisfies the requirement for doping control analysis to confirm the presence of 16 NSAIDs in equine plasma. The method also provides estimated equine plasma concentrations of select NSAIDs. The method is simple, fast, sensitive and reliable and is routinely used in the doping control analysis of these agents in plasma samples collected from racehorses post competition in PA.

\section{References}

[1] Russeva, V. and Mihailova, D. (1995) Binding of Phenylbutazone to Human Serum Albumin-Characterization and Identification of Binding Sites. Arzneimittel Forschung/Drug Research, 49, 255-258.

[2] Rahim, S. and Anne-Francoise, A. (1995) Location of Binding Sites on Immobilized Human Serum Albumin for Some Nonsteroidal Anti-inflammatory Drugs. Journal of Pharmaceutical Sciences, 84, 949-952. http://dx.doi.org/10.1002/jps.2600840809

[3] Gerrig, E.L., Lees, P. and Taylor, J.B. (1981) Pharmacokinetics of Phenylbutazone and Its Metabolites in the Horse. Equine Veterinary Journal, 13, 152-157. http://dx.doi.org/10.1111/j.2042-3306.1981.tb03472.x

[4] Van Eenoo, P., Delbeke, F.T., Roels, K. and Baert, K. (2003) Detection and Disposition of Tolmetin in the Horse. Journal of Pharmaceutical and Biomedical Analysis, 31, 723-730. http://dx.doi.org/10.1016/S0731-7085(02)00687-8

[5] You, Y.W., Uboh, C.E., Soma, L.R., Guan, F.Y., Li, X.Q., Rudy, J.A. and Chen, J.W. (2008) Screening, Quantification, and Confirmation of Phenylbutazone and Oxyphenbutazone in Equine Plasma by Liquid Chromatography-Tandem Mass Spectrometry. J. Anal. Toxicol. 33, 41-50. http://dx.doi.org/10.1093/jat/33.1.41

[6] Dirikolu, L., Woods, W.E., Boyles, J., Lehner, A.J., Harkins, J.D., Fisher, M., Schaeffer, D.J. and Tobin, T. (2009) Nonsteroidal Anti-Inflammatory Agents and Musculoskeletal Injuries in Thoroughbred Racehorses in Kentucky. Journal of Veterinary Pharmacology and Therapeutics, 32, 271-279.

http://dx.doi.org/10.1111/j.1365-2885.2008.01038.x

[7] Jones, E.W. and Hamm, D. (1978) Comparative Efficacy of Phenylbutazone and Naproxen in Induced Equine Myositis. Journal of Equine Medicine and Surgery, 2, 341-347.

[8] Soma, L.R., Uboh, C.E. and Maylin, G.A. (2012) The Use of Phenylbutazone in The Horse. Journal of Veterinary Pharmacology and Therapeutics, 35, 1-12. http://dx.doi.org/10.1111/j.1365-2885.2011.01299.x

[9] Insel, P.A. (1990) Analgesic-Antipyretics and Antiinflammatory Agents; Drugs Employed in The Treatment of Rheumatoid Arthritis and Gout. In: Goodman Gilman, A., Rail, T., Nies, A.S. and Taylor, P., Eds., The Pharmacological Basis of Therapeutics, Pergamon Press Inc., New York, 638-681.

[10] Kazemifard, A.G. and Moore, D.E. (1990) Liquid Chromatography with Amperometric Detection for The Determination of Non-Steroidal Anti-Inflammatory Drugs in Plasma. Journal of Chromatography A, 533, 125-132. http://dx.doi.org/10.1016/S0378-4347(00)82192-1

[11] Sun, Y., Takaba, K., Kido, H., Nakashima, M.N. and Nakashima, K. (2003) Simultaneous Determination of Arylpropionic Acidic Non-Steroidal Anti-Inflammatory Drugs in Pharmaceuitical Formulations and Human Plasma by HPLC with UV Detection. Journal of Pharmaceutical and Biomedical Analysis, 30, 1611-1619. 
http://dx.doi.org/10.1016/S0731-7085(02)00549-6

[12] Arcelloni, C., Lanzi, R., Pedercini, S., Molteni, G., Fermo, I., Pontiroli, A. and Paroni, R. (2001) High-Performance Liquid Chromatographic Determination of Diclofenac in Human Plasma after Solid-Phase Extraction. Journal of Chromatography B, 763, 195-200. http://dx.doi.org/10.1016/S0378-4347(01)00383-8

[13] Mikami, E., Goto, T., Ohno, T., Matsumoto, H., Inagaki, K., Ishihara, H. and Nishida, M. (2000) Simultaneous Analysis of Anthranilic Acid Derivatives in Pharmaceuticals and Human Urine by High-Performance Liquid Chromatography with Isocratic Elution. Journal of Chromatography B, 744, 81-89. http://dx.doi.org/10.1016/S0378-4347(00)00233-4

[14] Hirai, T., Matsumoto, S. and Kishi, I. (1997) Simultaneous Analysis of Several Non-Steroidal Anti-Inflammatory Drugs in Human Urine by High-Performance Liquid Chromatography with Normal Solid-Phase Extraction. Journal of Chromatography B, 692, 375-388. http://dx.doi.org/10.1016/S0378-4347(96)00509-9

[15] Battista, H.J., Wehinger, G. and Henn, R. (1985) Separation and Identification of Non-Steroidal Antirheumatic Drugs Containing a Free Carboxyl Function Using High-Performance Liquid Chromatography. Journal of Chromatography, 345, 77-89. http://dx.doi.org/10.1016/0378-4347(85)80137-7

[16] Heitmeier, S. and Blaschke, G. (1999) Direct Assay of Nonopioid Analgesics and Their Metabolites in Human Urine by Capillary Electrophoresis and Capillary Electrophoresis-Mass Spectrometry. Journal of Chromatography B, 721, 109-125. http://dx.doi.org/10.1016/S0378-4347(98)00483-6

[17] El Haj, B.M., Al Ainri, A.M., Hassan, M.H., Bin Khadem, R.K. and Marzouq, M.S. (1999) The GC/MS Analysis of Some Commonly Used Non-Steroidal Anti-Inflammatory Drugs (NSAIDs) in Pharmaceutical Dosage Forms and in Urine. Forensic Science International, 105, 141-153. http://dx.doi.org/10.1016/S0379-0738(99)00106-1

[18] Maure, H.H., Tauvel, F.X. and Kraemer, T. (2001) Screening Procedure for Detection of Non-Steroidal Anti-Inflammatory Drugs and Their Metabolites in Urine as Part of a Systematic Toxicological Analysis Procedure for Acidic Drugs and Poisons by Gas Chromatography-Mass Spectrometry after Extractive Methylation. Journal of Analytical Toxicology, 25, 237-244. http://dx.doi.org/10.1093/jat/25.4.237

[19] Hines, S., Pearce, C., Bright, J. and Teale, P. (2004) Development and Validation of a Quantitative Gas Chromatography Mass Spectrometry Confirmatory Method for Phenylbutazone in Equine Plasma. Chromatographia, 59, 109-114. http://dx.doi.org/10.1365/s10337-004-0243-7

[20] Clark, S.B., Turnipseed, S.B., Nandea, G.J. and Madson, M.R. (2004) Confirmation of Phenylbutazone Residues in Bovine Kidney by Liquid Chromatography/Mass Spectrometry. Journal of AOAC International, 85, 1009-1014.

[21] Hoof, N.V., Wasch, K.D., Poelmans, S., Noppe, H. and Brabander, H.D. (2004) Multi-Residue Liquid Chromatography/ Tandem Mass Spectrometry Method for the Detection of Non-Steroidal Anti-Inflammatory Drugs in Bovine Muscle: Optimization of Ion Trap Parameters. Rapid Communications in Mass Spectrometry, 18, 2823-2829. http://dx.doi.org/10.1002/rcm.1683

[22] Vinci, F., Fabbrocine, S., Fiori, M., Serpe, L. and Gallo, P. (2006) Determination of Fourteen Non-Steroidal Anti-Inflammatory Drugs in Animal Serum and Plasma by Liquid Chromatography/Mass Spectrometry. Rapid Communications in Mass Spectrometry, 20, 3412-3420. http://dx.doi.org/10.1002/rcm.2748

[23] Suenami, K., Lim, L.W., Takeuchi, T., Sasajima, Y., Sato, K., Takekoshi, Y. and Kanno, S. (2007) Online Sample Extraction and Enrichment of Non-Steroidal Anti-Inflammatory Drugs by Pre-Column in Capillary Liquid Chromatography Mass Spectrometry. Journal of Chromatography B, 846, 176-183. http://dx.doi.org/10.1016/j.jchromb.2006.08.041

[24] Heffron, B., Taddei, L., Benoit, M. and Negrusz, A. (2013) Quantification of Several Acidic Drugs in Equine Serum Using LC-MS-MS. Journal of Analytical Toxicology, 37, 600-604. http://dx.doi.org/10.1093/jat/bkt069

[25] Bethem, R., Boison, J., Gale, J., Heller, D., Lehotay, S., Loo, J., Musser, S., Price, P. and Stein, S. (2003) Establishing the Fitness for Purpose of Mass Spectrometric Methods. Journal of the American Society for Mass Spectrometry, 14, 528-541. http://dx.doi.org/10.1016/S1044-0305(03)00137-5 
Scientific Research Publishing (SCIRP) is one of the largest Open Access journal publishers. It is currently publishing more than 200 open access, online, peer-reviewed journals covering a wide range of academic disciplines. SCIRP serves the worldwide academic communities and contributes to the progress and application of science with its publication.

Other selected journals from SCIRP are listed as below. Submit your manuscript to us via either submit@scirp.org or Online Submission Portal.
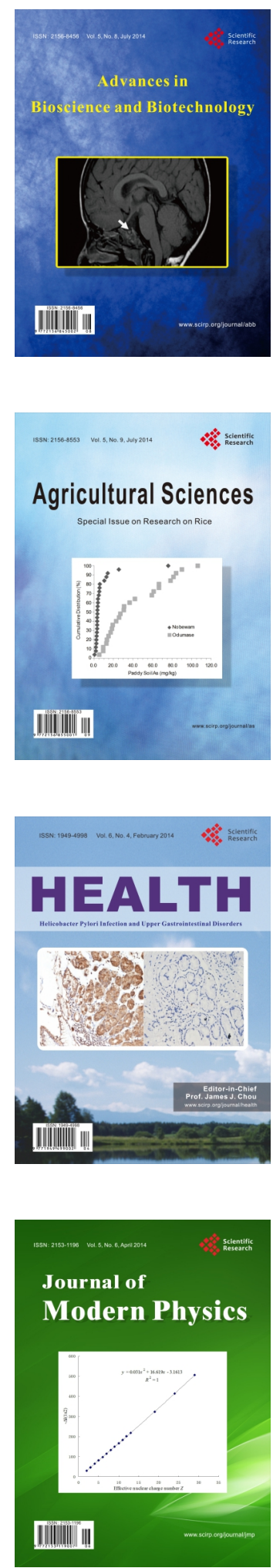
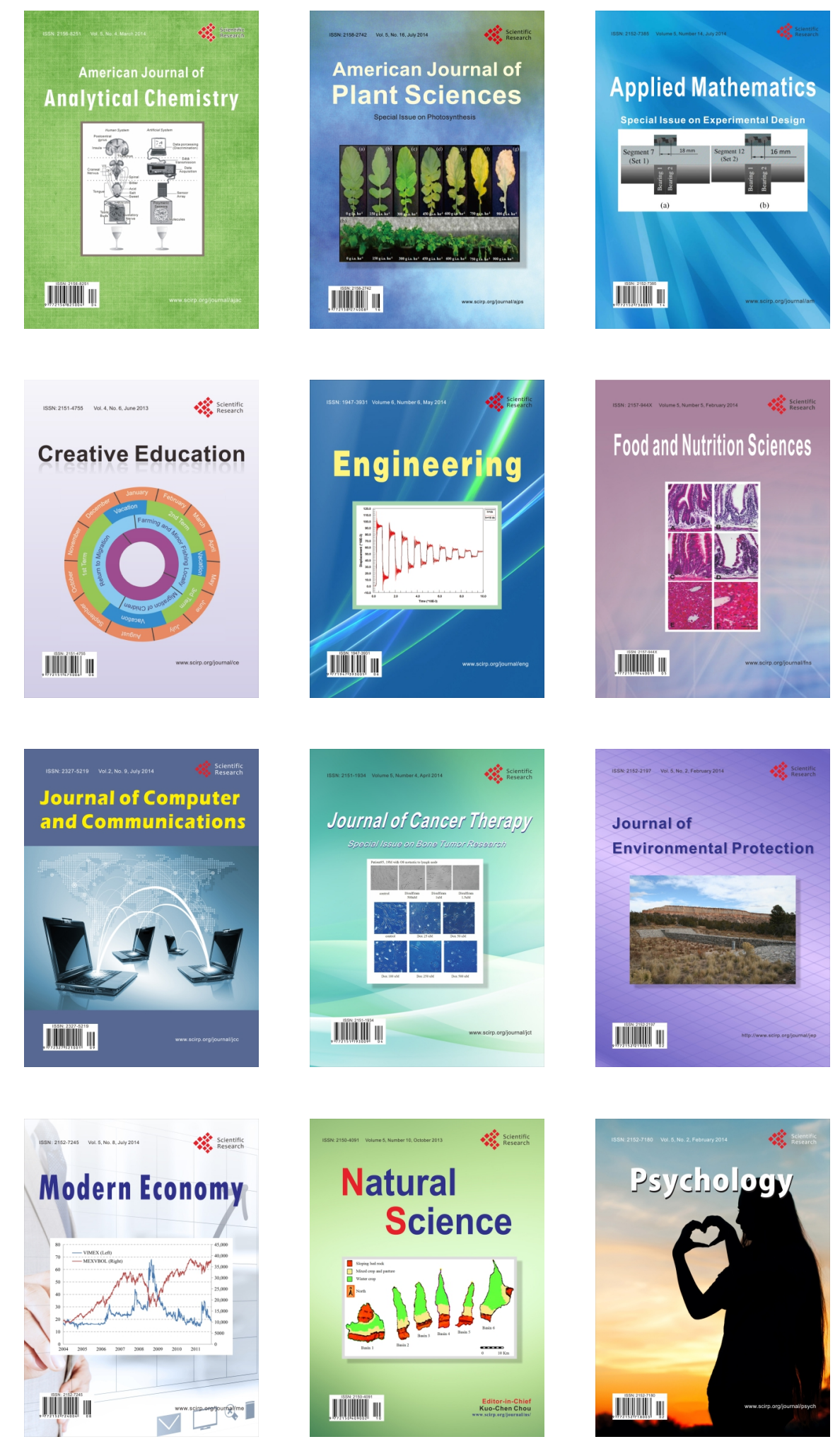